\title{
Strategy Model of Financing Empowerment Programs for Development Micro and Small Business: A Case Study of Pembiayaan Usaha Syariah Programs in Mojokerto City)
}

\author{
Risanda Alirastra Budiantoro ${ }^{1}$ \\ Pradipta Puspita Larasati ${ }^{2}$ \\ Sri Herianingrum ${ }^{3}$ \\ Islamic Economics, Faculty of Economics and Business, Universitas Airlangga, \\ Surabaya, Indonesia
}

\begin{abstract}
In business practices, micro and small businesses (SMEs) have several internal and external problems, such as difficulties in capital. These problems also occur in SMEs in Mojokerto. To solve this SME problem, several stakeholders in Mojokerto collaborated to create a Sharia Financing Program (PUSYAR) on the basis of a Murabahah contract. The implementation of this program has been running for approximately five years, since the memorandum of understanding was signed by the Badan Amil Zakat Nasional Kota Mojokerto, PT. BPRS Kota Mojokerto, Dinas Koperasi Perindustrian dan Perdagangan (Diskoperindag) dan Masyarakat Ekonomi Syariah (MES) in 2013. During this time, the amount of budget allocation and realization, and the number of beneficiaries of the PUSYAR program has increased, so basically the PUSYAR financing program is needed by SMEs to survive the existing business competition. The renewal of this study, describes the PUSYAR program model as a whole and formulates a development strategy by strengthening the roles and responsibilities of the stakeholders involved. Therefore, the aim of this study will be to examine more deeply in formulating the right development strategy of the SME empowerment program through the PUSYAR financing program, so that the usefulness of this program can increase. The hope of the study result can be used as a reference for other local governments or the central government to apply this PUSYAR program in the future.
\end{abstract}

Keywords: Development Strategy, PUSYAR, SME Empowerment.

\footnotetext{
${ }^{1}$ Risanda Alirastra Budiantoro is a Student of MSi in Islamic Economics, Faculty of Economics and Business, Universitas Airlangga, Surabaya, Indonesia, Email: risanda.abe@gmail.com

2 Pradipta Puspita Larasati is a Student of MSi in Islamic Economics, Faculty of Economics and Business, Universitas Airlangga, Surabaya, Indonesia, Email: pradiptap196@gmail.com

${ }^{3}$ Sri Herianingrum is a Lecturer of MSi in Islamic Economics, Faculty of Economics and Business, Universitas Airlangga, Surabaya, Indonesia, Email: sriheria@gmail.com
} 
Model Strategi Pengembangan Pembiayaan Usaha Mikro dan Kecil: Studi Kasus Pada Program Pembiayaan Usaha Syariah Di Kota Mojokerto

Risanda A. Budiantoro, Pradipta P. Larasati, dan Sri Herianingrum

I. Pendahuluan

1.1. Latar Belakang

Kegiatan perekonomian di Indonesia masih didominasi oleh usaha-usaha skala mikro dan kecil dengan pelaku utama para petani, buruh tani, pedagang sarana produksi dan hasil pertanian, pengolahan hasil pertanian, serta industri rumah tangga. Menurut Badan Pusat Statistik (2010) Usaha Mikro Kecil Menengah (UMKM) merupakan salah satu komponen pelaku usaha yang mempunyai sumbangan cukup besar dalam menciptakan lapangan pekerjaan. Oleh sebab itu keberadaan usaha mikro dan kecil (UMK) sangat dibutuhkan masyarakat khususnya masyarakat dengan kemampuan ekonomi dan keterampilan terbatas. Peranan penting usaha mikro dan kecil dalam kehidupan masyarakat adalah sebagai tempat mendapatkan penghasilan dan mengembangkan potensi atau keterampilan yang mereka miliki (Maryati, 2014). Usaha mikro dan kecil berkontribusi sebesar 96,71 persen terhadap penyerapan tenaga kerja di Indonesia dan sebesar 61,41 persen terhadap PDB, hal tersebut menunjukkan tingginya kontribusi usaha mikro dan kecil terhadap kondisi perekonomian Indonesia (Badan Pusat Statistik, 2015).

Dalam menjalankan usahanya, usaha mikro dan kecil di Indonesia seringkali mengalami berbagai kesulitan dalam menjalankan usahanya seperti kesulitan permodalan, kesulitan bahan baku, dan kesulitan pemasaran dan masalah permodalan menjadi kesulitan utama dalam usaha tersebut (Badan Pusat Statistik, 2015). Dalam rangka membantu pelaku usaha mikro dan kecil (UMK) di Kota Mojokerto, Badan Amil Zakat Nasional Kota Mojokerto dan PT. BPRS Kota Mojokerto, Pemerintah Kota Mojokerto melalui Dinas Koperasi Perindustrian dan Perdagangan (Diskoperindag) dan Masyarakat Ekonomi Syariah (MES) membentuk sebuah Program Pembiayaan Syariah (PUSYAR). Pelaksanaan program tersebut merupakan bantuan pinjaman modal berbasis syariah dengan akad Murabahah kepada pemilik usaha mikro dan kecil di Mojokerto. Usaha mikro dan kecil penerima manfaat dari Program PUSYAR tersebar di seluruh kelurahan yang ada di Kota Mojokerto (lihat Tabel 1).

Berdasarkan data dari Baznas Kota Mojokerto (2012-2016), menggambarkan penyebaran 18 kelurahan di Kota Mojokerto yang 
memperoleh program PUSYAR. Pada 2015, menunjukkan bahwa jumlah penerima manfaat dari program PUSYAR terbesar berada di kelurahan Wates sebanyak 27 UMK. Sementara secara keseluruhan total penerimaan program PUSYAR terbanyak ada di Kelurahan Surodinawan.

Tabel 1. Penyebaran Usaha Mikro dan Kecil Penerima Manfaat Program PUSYAR

\begin{tabular}{|l|c|c|c|c|c|}
\hline \multicolumn{1}{|c|}{ Kelurahan } & $\begin{array}{c}2012 \\
\text { (Jilid 1) }\end{array}$ & $\begin{array}{c}2013 \\
\text { (Jilid 1) }\end{array}$ & $\begin{array}{c}2014 \\
\text { (Jilid 1) }\end{array}$ & $\begin{array}{c}2015 \\
\text { (Jilid 1) }\end{array}$ & $\begin{array}{c}2015 \\
\text { (Jilid 2) }\end{array}$ \\
\hline Blooto & 16 & 16 & 13 & 13 & 5 \\
\hline Prajuritkulon & 3 & 3 & 9 & 14 & 6 \\
\hline Surodinawan & 13 & 16 & 27 & 22 & 4 \\
\hline Miji & 5 & 7 & 6 & 13 & 8 \\
\hline Kaliman & 3 & 1 & 4 & 2 & - \\
\hline Pulorejo & 13 & 11 & 16 & 6 & - \\
\hline Kranggan & 11 & 11 & 17 & 15 & 4 \\
\hline Mentikan & 3 & 2 & 5 & 3 & - \\
\hline Balongsari & 8 & 4 & 6 & 5 & 1 \\
\hline Sentanan & 2 & 1 & 2 & 3 & - \\
\hline Jagalan & 4 & 1 & 2 & 4 & - \\
\hline Magersari & 2 & 5 & 7 & 2 & 2 \\
\hline Wates & 10 & 11 & 31 & 23 & 4 \\
\hline Kedundung & 5 & 6 & 7 & 13 & 4 \\
\hline Gunung Gedangan & 1 & 3 & 4 & 8 & - \\
\hline Meri & 23 & 18 & 13 & 21 & 1 \\
\hline Purwotengah & 0 & 1 & 2 & 7 & - \\
\hline Gedongan & 2 & 4 & 3 & 4 & - \\
\hline Jumlah & 124 & 121 & 174 & 178 & 39 \\
\hline
\end{tabular}

Sumber: Badan Amil Zakat Nasional Kota Mojokerto, (2012-2016)

Meski program PUSYAR tergolong baru, namun jumlah penerima manfaat PUSYAR setiap tahunnya terus meningkat, dari beberapa wacana yang ada untuk terus memastikan bahwa setiap lapisan masyarakat yang memiliki usaha mikro dan kecil dapat menggunakan dan menerima manfaat dari program ini. Wahyudi, Khusaini, dan Pratomo (2016) melakukan penelitian terkait pemberdayaan usaha mikro dan kecil di Kota Mojokerto melalui program PUSYAR yang berbasis prinsip-prinsip syariah. Walaupun program tersebut telah mampu memberdayakan ribuan pelaku usaha mikro dan kecil, namun hasilnya masih terdapat kendala bagi UMK, kurangnya informasi mengenai sumber-sumber permodalan, serta persyaratan pengajuannya. Sehingga pemerintah perlu meningkatkan aksesibilitas pelaku usaha mikro dan kecil serta seluruh masyarakat Mojokerto. Sehingga, strategi pengembangan perlu dilakukan. 


\subsection{Permasalahan}

Masalah yang dibahas dalam penelitian ini dibatasi pada strategi pengembangan pemberdayaan usaha mikro dan kecil dalam program PUSYAR yang dilaksanakan di Kota Mojokerto. Penelitian secara khusus akan melihat skema, tanggung jawab stakeholderyang terlibat dan pengembangan program PUSYAR kedepannya. Kajian ini menjadi penting untuk dilakukan karena program yang sudah berjalan sejak 2012 ini memiliki tujuan yang baik untuk meningkatkan kemandirian ekonomi bagi usaha mikro dan kecil potensial yang ada di Kota Mojokerto. Bertitik tolak dari latar belakang masalah sebagaimana dikemukakan diatas, maka dapat dirumuskan beberapa masalah kajian sebagai berikut:

1. Bagaimana konsep program PUSYAR?

2. Bagaimana peran stakeholderyang terlibat dalam program PUSYAR?

3. Bagaimana strategi pengembangan program pemberdayaan usaha mikro dan kecil dalam perspektif Islam?

\subsection{Kerangka Berpikir}

Untuk memperjelas pelaksanaan penelitian maka perlu dijelaskan suatu kerangka pemikiran. Adapun kerangka pemikiran dalam penelitian ini adalah sebagai berikut: 


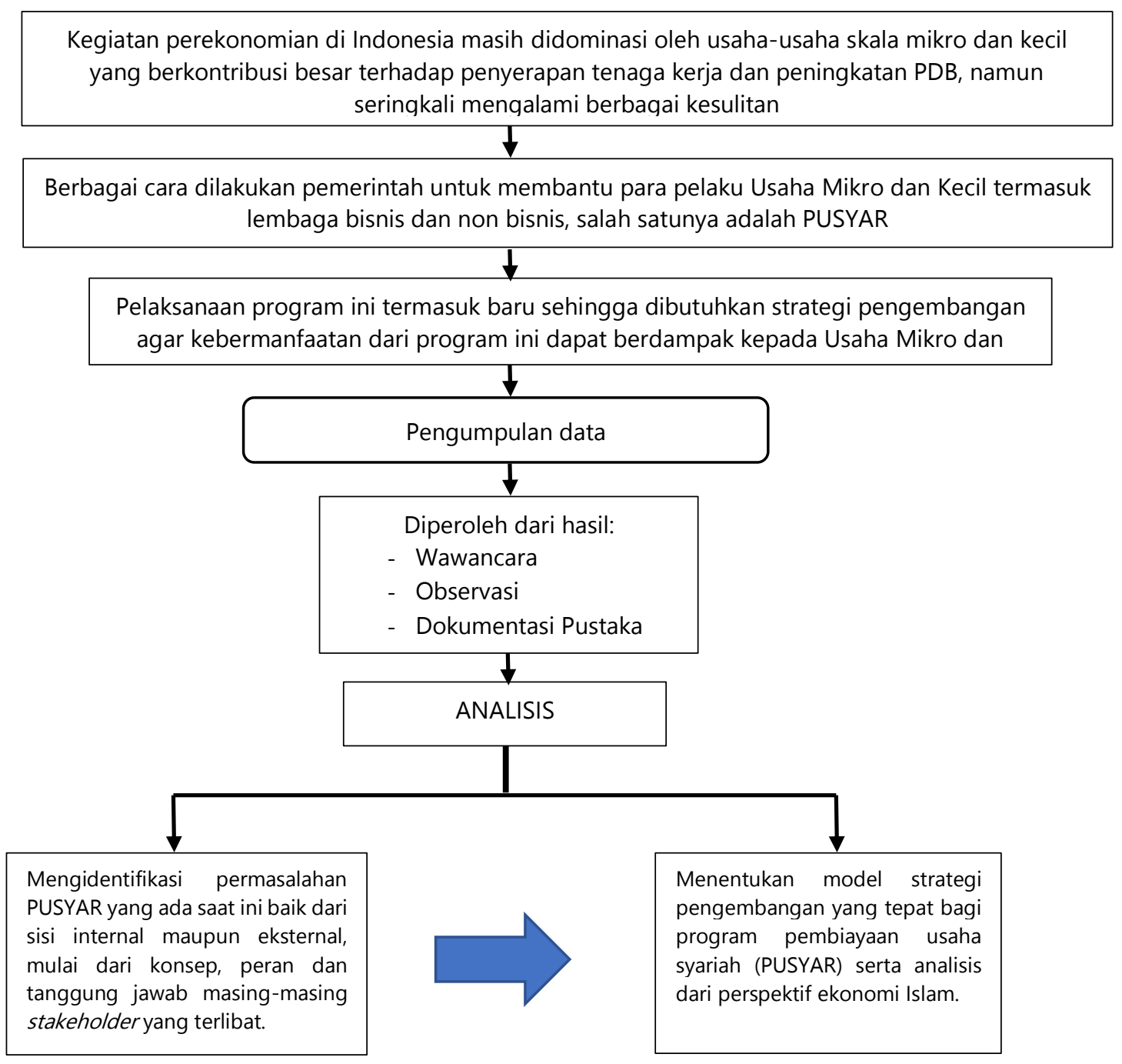

II. Tinjauan Literatur

\subsection{Usaha Mikro dan Kecil (UMK)}

Sebelum menentukan strategi pengembangan pemberdayaan usaha mikro dan kecil, perlu kiranya untuk mengetahui definisi dan kriteria dari Usaha Mikro dan Kecil. Namun, salah satu permasalahannya tidak adanya pengertian yang berlaku secara universal tentang Usaha Mikro dan Kecil. Definisi Usaha Mikro dan Kecil yang berlaku di Indonesia berlandaskan pada UU No. 20 Tahun 2008 tentang Usaha Mikro, Kecil dan Menengah yang didasari kepada nilai kekayaan bersih dan nilai hasil penjualan (lihat Tabel 2). 
Risanda A. Budiantoro, Pradipta P. Larasati, and Sri Herianingrum

Tabel 2. Definisi dan Kriteria Usaha Mikro, Kecil dan Menengah (UMKM)

\begin{tabular}{|c|c|}
\hline Skala Usaha & Definisi dan Kriteria \\
\hline Usaha mikro & $\begin{array}{l}\text { - Memiliki kekayaan bersih maksimal Rp. } 50 \text { juta (tidak } \\
\text { termasuk tanah dan bangunan tempat usaha) } \\
\text { - Memiliki hasil penjualan tahunan sampai Rp. } 300 \text { juta }\end{array}$ \\
\hline Usaha Kecil & $\begin{array}{l}\text { - Memiliki kekayaan bersih lebih dari Rp. } 50 \text { juta sampai } \\
\text { dengan Rp. } 500 \text { juta (tidak termasuk tanah dan } \\
\text { bangunan tempat usaha) } \\
\text { - Memiliki hasil penjualan tahunan lebih dari Rp. } 300 \\
\text { juta sampai dengan Rp. 2,5 milyar }\end{array}$ \\
\hline Usaha menengah & $\begin{array}{l}\text { - Memiliki kekayaan bersih lebih dari Rp. } 500 \text { juta } \\
\text { sampai dengan Rp. } 10 \text { milyar (tidak termasuk tanah } \\
\text { dan bangunan tempat usaha) } \\
\text { - Memiliki hasil penjualan tahunan lebih dari Rp. 2,5 } \\
\text { milyar sampai dengan Rp. } 10 \text { milyar }\end{array}$ \\
\hline
\end{tabular}

Sumber: UU No. 20 Tahun 2008 Tentang Usaha Mikro, Kecil dan Menengah

Usaha mikro dan kecil yang potensial dapat mengikuti program pembiayaan PUSYAR ini dengan melengkap sejumlah persyaratan yang dibutuhkan, antara lain:

Tabel 3. Kriteria dan Syarat UMK untuk Mengikuti Program PUSYAR

\begin{tabular}{|c|l|c|l|}
\hline No & \multicolumn{1}{|c|}{ Kriteria } & No & \multicolumn{1}{|c|}{ Syarat } \\
\hline 1 & $\begin{array}{l}\text { Nasabah adalah warga Kota } \\
\text { Mojokerto }\end{array}$ & 1 & $\begin{array}{l}\text { Fotocopy KTP suami dan } \\
\text { istri }\end{array}$ \\
\hline 2 & $\begin{array}{l}\text { Memiliki aset usaha kurang dari } \\
\text { Rp. 500 Juta }\end{array}$ & 2 & $\begin{array}{l}\text { Fotocopy Kartu Keluarga } \\
\text { dan Surat Nikah }\end{array}$ \\
\hline 3 & $\begin{array}{l}\text { Telah memperoleh rekomendasi } \\
\text { tertulis dari Diskoperindag dan } \\
\text { BAZ Kota Mojokerto (diproses oleh } \\
\text { BAZ Mojokerto) }\end{array}$ & 3 & Materai \\
\hline 4 & $\begin{array}{l}\text { Tidak mempunyai tunggakan } \\
\text { pinjaman di Diskoperindag (black } \\
\text { list) atau bank lain. }\end{array}$ & 4 & Jaminan asli \\
\hline 5 & $\begin{array}{l}\text { Bersedia membuka rekening } \\
\text { tabungan di BPR Syariah Kota } \\
\text { Mojokerto sebagai aktivis usaha }\end{array}$ & 5 & Surat keterangan Domisili \\
\hline & \multicolumn{1}{|c|}{6} & Surat keterangan Usaha \\
\hline
\end{tabular}




\subsection{Strategi Pengembangan dan Konsep Pemberdayaan dalam Islam}

Strategi pengembangan merupakan bakal tindakan yang menuntut pengambilan keputusan pada manajemen puncak didalam melakukan pengembangan usaha untuk direalisasikannya. Sehingga dalam hal ini strategi pengembangan berorientasi ke masa depan. Strategi pengembangan mempunyai fungsi perumusan dan dalam mempertimbangkan faktor-faktor internal maupun eksternal yang dihadapi perusahaan (David, 2004). Strategi pengembangan yang dirumuskan bersifat lebih spesifik tergantung kegiatan fungsional manajemen (Hunger and Wheelen, 2003). Strategi pengembangan berisikan rencana yang disatukan secara menyeluruh dan terpadu yang mengaitkan keunggulan strategi perusahaan dengan tantangan lingkungan dan dirancang untuk memastikan bahwa tujuan utama dapat dicapai melalui pelaksanaan yang tepat (Jauch dan Glueck, 1988; Umar, 2001).

Dalam Islam, pengembangan atau pemasaran bisnis disertai dengan keikhlasan semata-mata hanya untuk mencari keridhaan Allah, maka seluruh bentuk transaksi menjadi ibadah dihadapan Allah SWT (Idri, 2015). Hal ini akan menjadi bibit dan modal besar baginya untuk tumbuh menjadi bisnis yang besar, yang represent (mewakili) spritual brand, yang memiliki kharisma, keunggulan dan keunikan yang tak tertandingi (Rahman, 2003). Dalam Islam kegiatan pengembangan atau pemasaran hal-hal lain yang dapat merugikan konsumen harus berusaha untuk dihindari.

Pengembangan juga merupakan bagian dari praktik muamalah berdasarkan prinsip syariah Islam yang melibatkan pihak-pihak yang berkepentingan guna memperoleh manfaat dan nilai. Dalam kaidah fikih praktik pemasaran relevan dengan ungkapan:

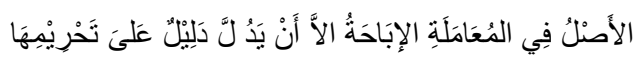

Artinya: "Pada dasarnya semua bentuk muamalat (bisnis) boleh dilakukan kecuali ada dalil yang mengharamkannya".

Pengembangan syariah menurut definisi adalah penerapan suatu bisnis strategi yang sesuai dengan nilai dan prinsip syariah. Menurut Arif (2012) ada beberapa nilai-nilai dalam pengembangan syariah yang mengambil konsep dari keteladanan sifat Rasulullah SAW, yaitu:

1. Shiddiq, artinya memiliki kejujuran dan selalu melandasi ucapan, keyakinan, serta perbuatan berdasarkan ajaran Islam, tidak ada satu ucapan pun yang perbuatan berdasarkan ajaran Islam, tidak ada satu ucapan pun yang saling bertentangan dengan perbuatan.

2. Fathanah, berarti mengerti, memahami, dan menghayati secara mendalam segala hal yang terjadi dalam tugas dan kewajiban.

3. Amanah, artinya memiliki makna tanggung jawab dalam melaksanakan setiap tugas dan kewajiban, amanah ditampilkan dalam keterbukaan, 
kejujuran, pelayanan prima dan ihsan (berupa menghasilkan yang terbaik) dalam segala hal, sikap ini harus memiliki oleh setiap mukmin apalagi yang memiliki pekerjaan yang terkait dengan pelayanan kepada masyarakat.

4. Tabligh, artinya mengajarkan sekaligus memberikan contoh kepada pihak lainnya untuk melaksanakan ketentuan-ketentuan ajaran Islam dalam setiap gerak aktivitas ekonomi yang dilakukan sehari-hari.

5. Istiqomah, artinya konsisten. Hal ini memberikan makna seorang pengembangan syariah dalam praktik pengembangan selalu istiqomah dalam penerapan aturan syariah, pengembangan syariah harus dapat dipegang janji, tidak dikenakan seorang pengembang syariah berubahubah dalam memberikan janji.

Mengingat besarnya peran usaha mikro dan kecil dalam mendorong perekonomian maka perlu untuk merumuskan konsep pemberdayaan yang tepat guna, baik secara bantuan teknis dan pengembangan kelembagaan yang memadai. Menurut Jim Life (1995:56) dalam Suharto (1997) pemberdayaan berasal dari bahasa inggris empowerment, yang secara harfiah bisa diartikan sebagai pemberkuasaan, dalam arti pemberian atau peningkatan kekuasaan (power) kepada masyarakat yang lemah atau tidak beruntung (disanvantaged). Pemberdayaan (empowerment) merupakan alat penting dan strategis untuk memperbaiki, memperbaharui, dan meningkatkan kinerja organisasi baik organisasi yang bergerak dalam kegiatan pemerintahan maupun organisasi yang bergerak dalam kegiatan dunia usaha (Diklatpim, 2008). Jadi, pemberdayaan adalah upaya untuk membangun daya (masyarakat) dengan mendorong, memotivasi dan membangkitkan kesadaran akan potensi yang dimilikinya serta berupaya untuk mengembangkannya (Mubyartanto, 2000).

III. Metode Penelitian

\subsection{Pendekatan Penelitian}

Jenis penelitian yang digunakan dalam penelitian ini adalah metode kualitatif. Penerapan metode kualitatif ini dengan pertimbangan kemungkinan data yang diperoleh di lapangan berupa data dalam bentuk fakta yang perlu adanya analisis yang secara mendalam terhadap penentuan strategi pengembangan pemberdayaan usaha mikro dan kecil di Kota Mojokerto melalui program PUSYAR.

\subsection{Fokus Penelitian}

Fokus penelitian adalah strategi pengembangan pemberdayaan usaha mikro dan kecil di Mojokerto. Jenis penelitian ini adalah studi kasus dengan objek penelitian program PUSYAR yang dijalankan atas kerjasama BPRS, BAZ, MES dan Diskouminaker. 


\subsection{Jenis dan Sumber Data}

Jenis data yang digunakan adalah data primer dan data sekunder yang diperoleh dari beberapa laporan yang dikeluarkan oleh instansi yang terlibat dari pelaksanaan program PUSYAR ini dari 2012-2017 dan literatur lainnya yang berkaitan dengan pengembangan strategi pemberdayaan usaha mikro dan kecil.

\subsection{Alat Analisis}

Pada penelitian studi kasus ini penulis menggunakan data time series yang analisisnya menggunakan deskriptif, dimana data diperoleh melalui observasi (field research), wawancara, serta dokumentasi pustaka.

a. Teknik observasi langsung, peneliti secara langsung melakukan pengamatan kepada objek yang diteliti;

b. Teknik wawancara dilakukan secara mendalam depth interview dimana peneliti melakukan wawancara secara langsung.

c. Teknik dokumentasi dan kepustakaan menggunakan jurnal yang sudah terpublikasi.

\section{Pembahasan}

\subsection{Gambaran Umum Program Pembiayaan Usaha Syariah (PUSYAR)}

PUSYAR merupakan program pembiayaan usaha syariah kepada pelaku usaha mikro dan kecil (UMK) yang berada di Kota Mojokerto. Dalam program ini tidak membebankan biaya tambahan apapun kepada peminjam karena biaya margin, administrasi dan asuransi ditanggung oleh Badan Amil Zakat Nasional Kota Mojokerto yang diambil dari dana infaq dan sedekah. Pelaksanaan program PUSYAR ini berlandaskan pada Perda No. 03 Pasal 20 Ayat 3 Tahun 2010 tentang Pengelolaan Zakat, Infaq dan sedekah yang kemudian diaplikasikan pada nota kesepahaman kerjasama PUSYAR yang ditandatangani secara bersama pada Selasa 9 April 2013.

Program Pembiayaan Usaha Syariah (PUSYAR) ini merupakan kerjasama antara Badan Amil Zakat Nasional Kota Mojokerto dengan PT. BPRS Kota Mojokerto, Pemerintah Kota Mojokerto melalui Dinas Koperasi Perindustrian dan Perdagangan (Diskoperindag) dan Masyarakat Ekonomi Syariah (MES) sebagai langkah konkrit dalam pemberdayaan usaha mikro dan kecil (UMK) di Kota Mojokerto, dengan cara memberikan pinjaman modal berbasis syariah dengan akad Murabahah. Gambaran program PUSYAR (Lihat Gambar 1) adalah BPRS akan memberikan pembiayaan atau pinjaman dana kepada pengusaha mikro dan kecil sebesar harga barang, dan nasabah wajib membayar kembali kepada bank sebesar harga barang dan keuntungannya (margin) secara angsuran. Namun keuntungannya margin dan biaya administrasi dan asuransi dibebankan kepada BAZ Kota Mojokerto. 
Gambar 1. Skema Program Pembiayaan Usaha Syariah

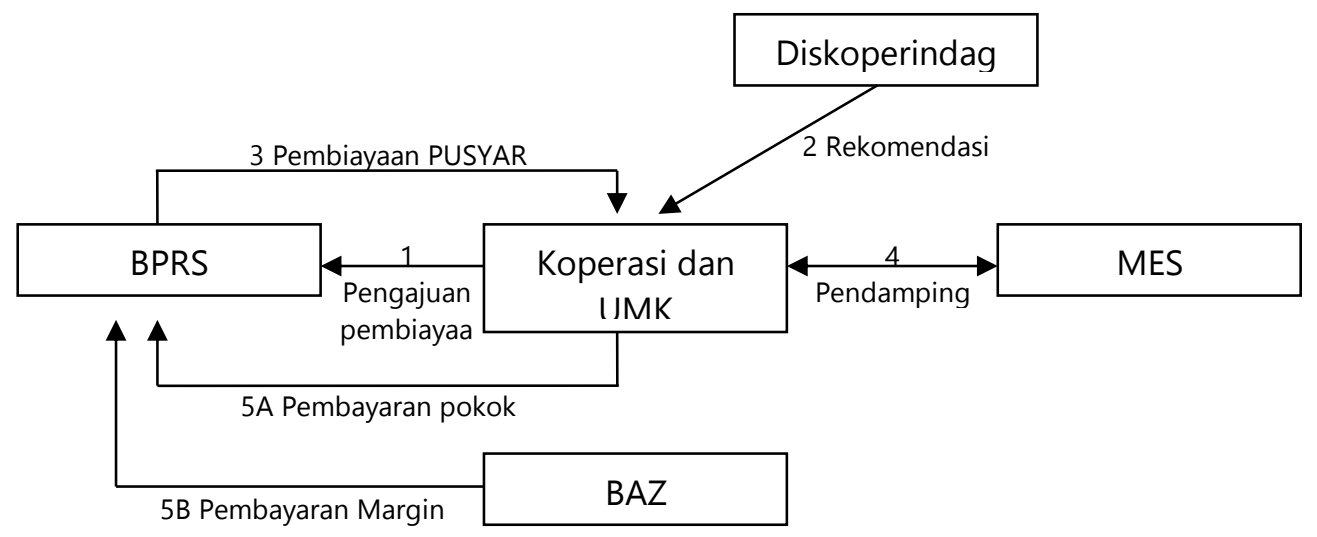

Sumber: Bank Indonesia dan Universitas Airlangga (2016: 32)

Keterangan:

1. Koperasi dan UMK melakukan pengajuan pembiayaan ke BPRS

2. Pemerintah melalui Diskoperindag memberikan rekomendasi UMK yang layak untuk diberikan pembiayaan.

3. BPRS memberikan bantuan pembiayaan Program PUSYAR kepada UMK yang sudah diberikan rekomendasi kelayakan

4. Selama masa pembiayaan, MES memberikan pendampingan dan pembinaan kepada UMK untuk meningkatkan daya saing dan kebermanfaatan program PUSYAR.

5A. UMK hanya berkewajiban membayar pokok dari pembiayaan yang sudah disalurkan oleh BPRS.

5B. BAZ Mojokerto melalui dana infak bertanggung jawab atas margin pembiayaan, biaya administrasi dan biaya lainnya

Berdasarkan data Diskouminaker (lihat Tabel 4) dari kurang lebih 1.613 unit usaha mikro dan kecil yang tidak bankable sebanyak 748 unit atau sebesar 46,37 persen berhasil disentuh melalui program PUSYAR ini. Berikut rincian program PUSYAR selama lima tahun pertama:

Tabel 4. Total Alokasi, Realisasi dan Jumlah UMK Penerima Program PUSYAR

\begin{tabular}{|c|c|c|c|}
\hline Tahun & Total Alokasi (Rp) & Total Realisasi (Rp) & $\begin{array}{c}\text { Jumlah UMK } \\
\text { Penerima (Unit) }\end{array}$ \\
\hline 2012 & 1.000 .000 .000 & 990.000 .000 & 120 \\
\hline 2013 & 1.000 .000 .000 & 968.300 .000 & 117 \\
\hline 2014 & 1.500 .000 .000 & 1.440 .500 .000 & 174 \\
\hline 2015 & 3.000 .000 .000 & 2.830 .500 .000 & 219 \\
\hline 2016 & 1.000 .000 .000 & 1.010 .000 .000 & 118 \\
\hline
\end{tabular}

Sumber: Diskouminaker (2012-2017) 
Pelaksanaan program PUSYAR ini dimulai pada 2012, namun pada waktu tersebut masih berupa tahap percobaan, kemudian disahkan pada 2013, dan masih terus berlanjut hingga saat ini. Berdasarkan data dari Diskouminaker (2012-2016) menunjukkan bahwa alokasi dan realisasi dana PUSYAR selama lima tahun pelaksanaan program tersebut mengalami peningkatan, begitu pula jumlah UMK penerima manfaat dari program PUSYAR berfluktuatif dengan tren yang meningkat, sehingga diharapkan kebermanfaatan program PUSYAR ini terus bisa meningkat.

Badan Amil Zakat Nasional Kota Mojokerto melalui program PUSYAR ini, berusaha untuk meningkatkan pertumbuhan dan kemandirian secara ekonomi bagi masyarakat Kota Mojokerto. Sekaligus mencapai misi religius dalam mensyiarkan rukun Islam yang ketiga (zakat), melalui gerakan sadar zakat bagi masyarakat kota Mojokerto sehingga mampu memberikan rangsangan finansial dalam peningkatan ekonomi secara mandiri.

4.2. Peran Stakeholder yang Terlibat Program Pembiayaan Usaha Syariah (PUSYAR)

Stakeholder yang terlibat memiliki peran dan tanggung jawab yang sudah dijelaskan pada MoU (Memorandum of Understanding) atau dalam nota kesepakatan yang disetujui oleh semua pihak yang terlibat (lihat Tabel 5)

Tabel 5. Peran Stakeholderyang Terlibat dalam Program PUSYAR

\begin{tabular}{|c|c|c|}
\hline No & Stakeholder & Tanggung Jawab \\
\hline 1 & $\begin{array}{l}\text { PT. BPRS Kota } \\
\text { Mojokerto }\end{array}$ & $\begin{array}{l}\text { Bertanggung jawab dalam penyediaan dana } \\
\text { sebagai pinjaman yang diberikan kepada UMK di } \\
\text { Kota Mojokerto yang menjadi peserta program } \\
\text { PUSYAR dengan plafon Rp } 750.000 \text { sampai Rp } \\
\text { 10.000.000. setiap tahunnya PT BPRS Kota } \\
\text { Mojokerto sanggup untuk menyediakan dana } \\
\text { untuk PUSYAR sebesar Rp 1.000.000.000 }\end{array}$ \\
\hline 2. & $\begin{array}{c}\text { Badan Amil Zakat } \\
\text { Nasional Kota } \\
\text { Mojokerto }\end{array}$ & $\begin{array}{l}\text { Bertanggung jawab dalam menanggung biaya } \\
\text { yang timbul dari program PUSYAR, seperti: biaya } \\
\text { bagi hasil, biaya administrasi dan biaya asuransi } \\
\text { peserta program PUSYAR dan membayarkannya } \\
\text { kepada pihak PT BPRS Kota Mojokerto sesuai } \\
\text { kesepakatan. }\end{array}$ \\
\hline 3. & $\begin{array}{l}\text { Dinas Koperasi } \\
\text { Perindustrian dan } \\
\text { Perdagangan } \\
\text { Kota Mojokerto } \\
\text { (Diskoperindag) }\end{array}$ & $\begin{array}{l}\text { Bertanggung jawab dalam penyelesaian UMK } \\
\text { calon peserta program PUSYAR yang mengajukan } \\
\text { aplikasi pinjaman. Dalam hal ini, Diskoperindag } \\
\text { Kota Mojokerto berperan dalam menerbitkan } \\
\text { surat rekomendasi UMK yang berhak untuk } \\
\text { mengikuti program PUSYAR. }\end{array}$ \\
\hline
\end{tabular}


Risanda A. Budiantoro, Pradipta P. Larasati, and Sri Herianingrum

\begin{tabular}{|c|c|l|}
\hline 4. & $\begin{array}{c}\text { Masyarakat } \\
\text { Ekonomi Syariah } \\
(\mathrm{MES})\end{array}$ & $\begin{array}{l}\text { Bertanggung jawab dalam melakukan } \\
\text { pengawasan terhadap usaha peserta program } \\
\text { PUSYAR dan pembinaan terhadap UMK peserta } \\
\text { program PUSYAR dalam manajemen usaha. }\end{array}$ \\
\hline
\end{tabular}

4.3. Strategi Pengembangan Program Pemberdayaan Usaha Mikro dan Kecil melalui Program Pembiayaan Usaha Syariah (PUSYAR)

Sebelum merumuskan strategi pengembangan usaha mikro dan kecil di Kota Mojokerto secara tepat maka perlu untuk mengetahui permasalahan yang dihadapi oleh pelaku usaha mikro dan kecil di lapangan. Secara umum berbagai permasalahan yang dihadapi dapat diklasifikasikan menjadi dua aspek, yaitu aspek internal dan eksternal (lihat Tabel 6).

Tabel 6. Aspek Internal dan Eksternal atas Permasalahan Usaha Mikro dan Kecil di Kota Mojokerto

\begin{tabular}{|l|l|}
\hline \multicolumn{1}{|c|}{ Aspek Internal } & \multicolumn{1}{c|}{ Aspek Eksternal } \\
\hline $\begin{array}{l}\text { Kemampuan berinovasi masih } \\
\text { kurang. }\end{array}$ & $\begin{array}{l}\text { Kebijakan pemerintah yang kurang } \\
\text { responsif terhadap pengembangan } \\
\text { UMK. }\end{array}$ \\
\hline $\begin{array}{l}\text { Terjadi diseconomies of scale akibat } \\
\text { keterbatasan kapasitas produksi. }\end{array}$ & $\begin{array}{l}\text { Kondisi perbankan dengan tingkat } \\
\text { bunga yang tinggi dan proses kredit } \\
\text { yang berbelit. }\end{array}$ \\
\hline $\begin{array}{l}\text { Sumber dana untuk ekspansi usaha } \\
\text { minim. }\end{array}$ & $\begin{array}{l}\text { Kesulitan memperluas pangsa pasar } \\
\text { baru, khususnya pasar ekspor }\end{array}$ \\
\hline $\begin{array}{l}\text { Kualitas skil SDM masih rendah } \\
\text { sehingga kualitas produk belum } \\
\text { optimal. }\end{array}$ & $\begin{array}{l}\text { Ancaman produk serupa yang } \\
\text { berasal dari impor. }\end{array}$ \\
\hline $\begin{array}{l}\text { Ketersediaan bahan baku, terutama } \\
\text { untuk memenuhi pembeli skala } \\
\text { besar. }\end{array}$ & $\begin{array}{l}\text { Kondisi infrastruktur yang buruk } \\
\text { meningkatkan biaya distribusi. }\end{array}$ \\
\hline $\begin{array}{l}\text { Biaya produksi yang tinggi berakibat } \\
\text { pada mahalnya produk yang dijual. }\end{array}$ & $\begin{array}{l}\text { Kurangnya kontribusi pihak eksternal } \\
\text { dalam mendukung pengembangan } \\
\text { UMK. }\end{array}$ \\
\hline $\begin{array}{l}\text { Keterbatasan teknologi yang } \\
\text { digunakan. }\end{array}$ & \\
\hline
\end{tabular}

Sumber: Data Primer (diolah)

Jika dikaji dari aspek internal masalah yang dihadapi oleh UMK di Kota Mojokerto berasal dari sisi pelaku yaitu lingkungan internal perusahaan yang merupakan sekumpulan sumber daya, kapabilitas dan kompetensi inti. Menurut Barney (1991) sumber daya meliputi semua aset seperti keahlian, proses organisasi, atribut, informasi dan pengetahuan yang dikuasai oleh perusahaan 
dan yang menyebabkan perusahaan dapat menyusun dan mengimplementasikan strategi yang meningkatkan efisiensi dan efektivitas, sehingga aspek internal merupakan faktor utama dalam strategi pengembangan usaha. Sedangkan aspek eksternal berasal dari luar yang mendukung proses usaha serta ancaman dan risiko pasar di luar kehendak pelaku, sehingga, setelah mengetahui permasalahan yang dihadapi oleh Usaha Mikro dan Kecil di Kota Mojokerto baik dari sisi internal maupun eksternal diperlukan sebuah strategi pengembangan yang tepat guna mengembangkan Usaha Mikro dan Kecil di Kota Mojokerto. Karena menurut Anoraga (2007) pengembangan suatu usaha adalah tanggung jawab dari setiap pengusaha atau wirausaha yang membutuhkan pandangan kedepan, motivasi dan kreativitas. Jika hal ini dapat dilakukan oleh setiap wirausaha, maka besar harapan untuk dapat menjadikan usaha yang semula kecil menjadi skala menengah bahkan menjadi sebuah usaha besar. Berikut model strategi dan pengembangan Usaha Mikro Kecil melalui Program PUSYAR yang diadopsi dari model strategi dan pengembangan usaha milik Rosyadi dapat diterapkan oleh stakeholders (lihat Gambar 2).

Perumusan model strategi pemberdayaan usaha mikro dan kecil melalui program PUSYAR dibagi menjadi empat kategori, antara lain: input, proses, output dan outcome. Dimulai dari survei dan identifikasi permasalahan UMK baik internal dan eksternal yang dapat mempengaruhi kinerja UMK. Dari keseluruhan UMK yang ada di Kota Mojokerto, hanya UMK potensial yang dibuktikan dengan rekomendasi dari Diskoperindag yang berhak mendapatkan bantuan pembiayaan dengan basis akad Murabahah melalui program PUSYAR. Pelaksanaan program ini meliputi pelatihan secara teknis dan manajerial, sehingga diharapkan adanya perkembangan usaha yang signifikan. Selama program PUSYAR ini berlangsung juga terdapat pendampingan serta pengawasan dan pemantauan agar sesuai dengan rencana pengembangan usaha (bussiness plan). Hasil akhirnya diharapkan adanya kemandirian ekonomi yang dihadapi oleh UMK.

Dalam melakukan penyelesaian terhadap masalah yang dihadapi oleh usaha mikro dan kecil, maka dilaksanakan Program PUSYAR ini dengan pendekatan triple action yang terdiri dari pelatihan, pendampingan dan konsultasi (lihat Gambar 3) sebagai strategi pengembangan pemberdayaan usaha mikro dan kecil. 
Gambar 2. Model Strategi Pemberdayaan Usaha Mikro dan Kecil melalui Program PUSYAR

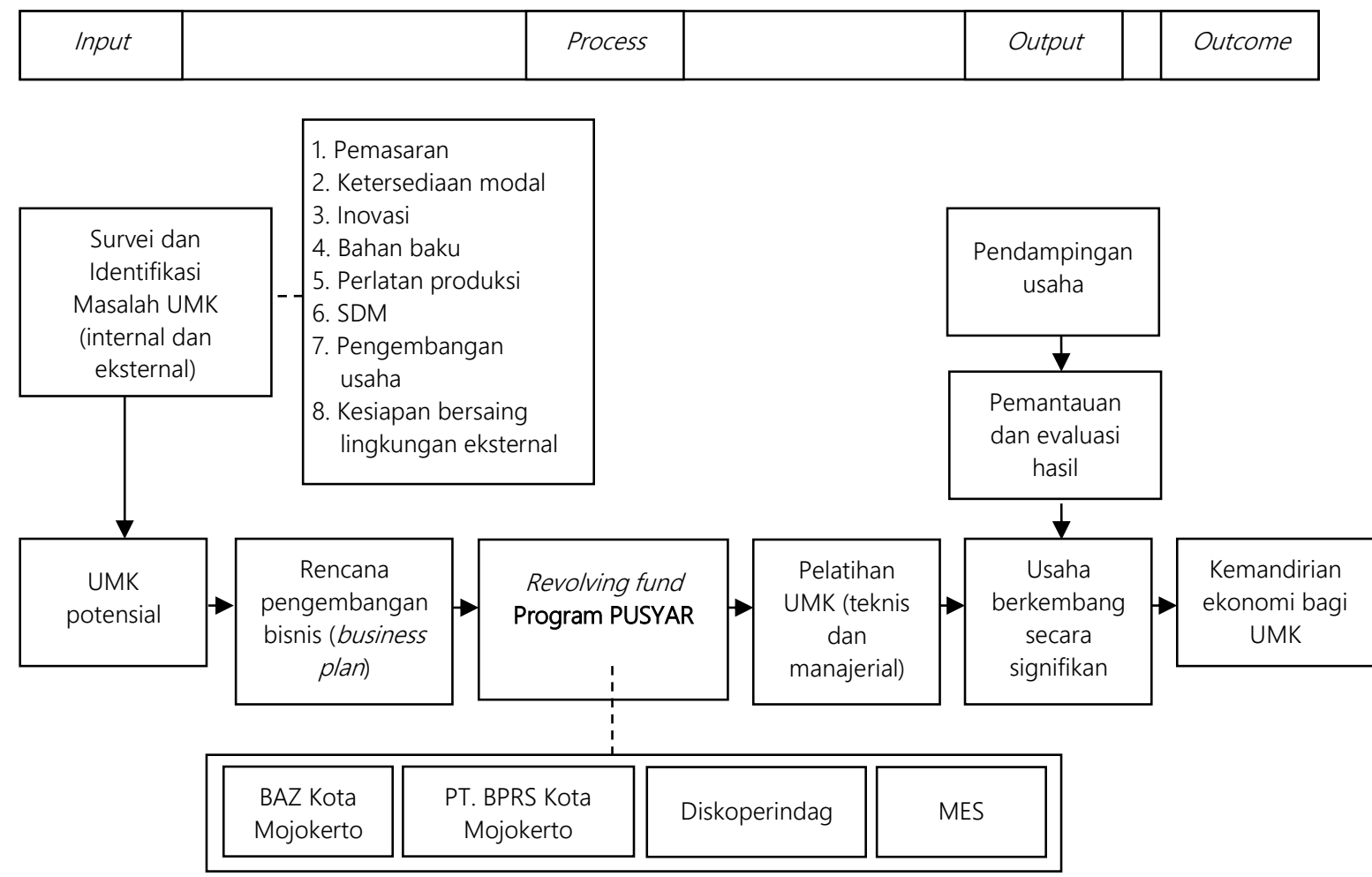

Sumber: Rosyadi (2013), dimodifikasi

\section{Gambar 3. Triple Action dalam Program PUSYAR}

\begin{tabular}{|l|}
\hline \multicolumn{2}{|c|}{ 1. Pelatihan } \\
Kegiatan pelatihan kepada \\
pelaku yang telah diidentifikasi \\
dengan melibatkan instansi yang \\
terlibat dalam PUSYAR. \\
Materi yang diberikan: \\
a. Pemahaman mengenai \\
peranan lembaga keuangan; \\
b. Pemahaman tentang pinjaman \\
modal dan dana bergulir \\
berbasis syariah. \\
c. Peningkatan kemampuan \\
berwirausaha (teknis dan \\
manajerial) \\
\hline
\end{tabular}

Apabila program PUSYAR menjalankan triple action ini, maka permasalahan yang dihadapi oleh UMK yang ada di Kota Mojokerto baik secara internal maupun eksternal akan selesai dan pada akhirnya akan terciptanya 
kemandirian ekonomi. Pelaksanaan triple action ini harus dilakukan secara bertahap dan terpadu, mulai dari pelatihan, pendampingan dan konsultasi.

\subsection{Analisis Strategi Pengembangan PUSYAR melalui Pemberdayaan dalam Perspektif Ekonomi Islam}

Strategi adalah langkah-langkah yang harus dijalankan oleh suatu perusahaan untuk mencapai tujuan dan tidak kalah dari pesaing-pesaingnya. Salah satu strategi pengembangan produk yang dilakukan oleh BPRS Kota Mojokerto dalam mengatasi pesaingnya adalah dengan melakukan pengembangan produk pembiayaan supaya lebih menarik banyak nasabah melalui program PUSYAR.

Menurut Alma dan Priansa (2014) pembiayaan dalam syariah sangat terikat erat dengan kegiatan dalam lembaga keuangan dengan prinsip syariah. Dalam pembiayaan syariah harus memenuhi beberapa aspek yaitu:

1. Aspek syariah, yaitu dalam setiap realisasinya, pembiayaan harus tetap berpedoman pada syariat Islam (antara lain tidak mengandung unsur maisir, gharar, dan riba serta bidang usaha harus halal).

2. Aspek ekonomi, yang artinya selain mempertimbangkan hal-hal syariat, perlu juga dipertimbangkan perolehan keuntungan, baik bagi lembaga keuangan maupun investor.

Pemberdayaan merupakan salah satu bentuk hubungan yang terjadi antar sesama manusia dan merupakan bagian integral dari muamalah, dengan muamalah dapat tercipta suatu masyarakat yang saling membantu. Suatu masyarakat dikatakan berdaya jika memiliki salah satu atau lebih dari beberapa variabel berikut. Pertama, memiliki kemampuan untuk memenuhi dasar hidup dan perekonomian yang stabil. Kedua, memiliki kemampuan beradaptasi dengan perubahan lingkungan. Ketiga, memiliki kemampuan menghadapi ancaman dan serangan dari luar. Keempat, memiliki kemampuan berkreasi dan berinovasi dalam mengaktualisasi diri dan menjaga eksistensinya bersama bangsa dan negara lain (Ismail, 2001).

Dari variabel yang ada dan dibahas dalam rancangan strategi pengembangan program PUSYAR sebelumnya dapat diketahui bahwa tujuan dari pengembangan PUSYAR telah sejalan dengan variabel berdaya yang intinya adalah mencapai kemandirian ekonomi bagi UMK. Selain itu, adanya program PUSYAR tersebut juga sejalan dengan tujuan ekonomi Islam (Barkatullah, 2011) yang terdiri atas tiga hal yaitu:

1. Menyediakan dan menciptakan peluang-peluang yang sama dan luas bagi semua orang untuk berperan serta dalam kegiatan ekonomi

Hal ini bisa dilihat dari tujuan PUSYAR yaitu meningkatnya kesejahteraan dan mendorong kemandirian UMK di Kota Mojokerto. Dalam hal ini PUSYAR memberikan peluang sama dalam bentuk bantuan 
permodalan kepada UMK potensial yang ada di kota Mojokerto untuk melakukan usaha atau mengembangkan usahanya serta memberi pelatihan dan pendampingan usaha bagi para pelaku UMK. Sehingga, tidak hanya para pemilik modal besar yang hanya dapat memiliki usaha, namun masyarakat miskin juga diberikan kesempatan untuk memiliki usaha serta berperan dalam kegiatan perekonomian.

2. Memberantas kemiskinan absolut, dan memenuhi kebutuhan dasar bagi semua individu masyarakat

Islam telah menetapkan kebutuhan primer manusia terdiri dari pangan, sandang dan papan. Terpenuhi ketiga kebutuhan tersebut selanjutnya menjadi penentu miskin tidaknya seseorang. Sebagai kebutuhan primer tentu pemenuhannya atas setiap individu, tidak dapat ditawar-tawar lagi. Oleh karena itu, Islam memberikan jaminan atas pemenuhan kebutuhan ini. Adanya jaminan pemenuhan kebutuhan primer bagi setiap individu, tidak berarti negara akan membagi-bagikan makanan, pakaian dan perumahan kepada siapa saja setiap saat. Sehingga masyarakat bisa bermalas-malasan karena kebutuhannya sudah dipenuhi. Ini anggapan yang salah. Maka dari itu PUSYAR hadir dengan memberikan bantuan berupa permodalan bagi masyarakat agar masyarakat bekerja dan mandiri dan lebih maju untuk memenuhi kebutuhan hidup sehingga terbebas dari kemiskinan.

3. Mencapai kebahagiaan di dunia dan di akhirat melalui suatu tata kehidupan yang baik dan terhormat.

V. Penutup

\subsection{Kesimpulan}

Berdasarkan analisis dan pembahasan dapat ditarik kesimpulan bahwa, program Pembiayaan Usaha Syariah (PUSYAR) merupakan kerjasama antara Badan Amil Zakat Nasional Kota Mojokerto dengan PT. BPRS Kota Mojokerto, Pemerintah Kota Mojokerto melalui Dinas Koperasi Perindustrian dan Perdagangan (Diskoperindag) dan Masyarakat Ekonomi Syariah (MES) sebagai langkah konkrit dalam pemberdayaan UMK di Kota Mojokerto, konsep dari program ini adalah memberikan pembiayaan pada Usaha Mikro dan Kecil dengan tidak membebankan biaya tambahan apapun kepada peminjam, karena biaya margin, administrasi dan asuransi ditanggung oleh Badan Amil Zakat Nasional Kota Mojokerto yang diambil dari dana infaq dan sedekah.

Semua stakeholder yang terlibat memiliki peran dan tanggung jawab masing-masing agar program pembiayaan ini berjalan dengan lancar, mulai dari PT. BPRS Kota Mojokerto yang bertanggung jawab dalam penyediaan dana sebagai pinjaman yang diberikan kepada UMK di Kota Mojokerto, Badan Amil Zakat bertanggung jawab dalam menanggung biaya yang timbul dari program PUSYAR, seperti: biaya bagi hasil, biaya administrasi dan biaya asuransi peserta 
program PUSYAR, Diskoperindag Kota Mojokerto bertanggung jawab dalam menyeleksi UMK calon peserta program PUSYAR dan melakukan pengawasan terhadap usaha peserta program PUSYAR dan pembinaan terhadap UMK peserta program PUSYAR dalam manajemen usaha yang dilakukan oleh Masyarakat Ekonomi Syariah (MES).

Strategi pengembangan program pemberdayaan usaha mikro dan kecil melalui program PUSYAR dibagi menjadi empat kategori, antara lain: input, proses, ouput dan outcome. Pengembangan program pemberdayaan akan berhasil apabila pelaku usaha mikro dan kecil serta para stakeholder yang terlibat bersinergi terhadap peran dan tanggungjawabnya masing-masing.

\subsection{Rekomendasi}

Beberapa rekomendasi yang dapat diberikan berdasarkan hasil penelitian diatas antara lain:

1. Bagi pelaku usaha mikro dan kecil

a. Pemilik usaha mikro dan kecil harus meningkatkan modal usaha dan skill yang dimilikinya karena pangsa pasar yang potensial tidak akan dapat diraih apabila kualitas dan kuantitas teknologi yang dimiliki tidak mendukung serta kapasitas produksi yang masih rendah.

b. Memanfaatkan program pemberdayaan syariah yang diberikan dengan tepat karena sebagai muslim harus dapat meningkatkan nilai-nilai Islam lebih mendalam pada setiap langkah ekonomi dan aktifitas yang mereka lakukan.

2. Bagi pengelola

a. Tetap mempertahankan program pemberdayaan pembiayaan syariah (PUSYAR) dengan baik agar menjadikan masyarakat mandiri, sejahtera dan mengurangi angka kemiskinan.

b. Meningkatkan jumlah UMK penerima manfaat agar terjadi pemerataan pada setiap masyarakat khususnya masyarakat yang mempunyai usaha dan mengalami kekurangan modal agar usaha mereka dapat lebih berkembang dan maju.

c. Peningkatan pendampingan pada pengawasan dan pengembangan usaha masyarakat seperti mengadakan pelatihan-pelatihan, pendampingan dan konsultasi agar usaha masyarakat lebih berkembang.

\section{Daftar Pustaka}

Al-Arif, M. Nur Rianto. 2012. Dasar-Dasar Pemasaran Bank Syariah. Bandung: Alfabeta.

Alma, Bukhari dan Donni Juni Priansa. 2004. Manajemen Bisnis Syariah: Menanamkan Nilai dan Praktis Syariah dalam Bisnis Kontemporer. Bandung: Alfabeta. 
Anoraga, Pandji. 2007. Pengantar Bisnis: Pengelolaan Bisnis dalam Era Globalisasi. Jakarta: Rineka Cipta.

Barkatullah, Abdul Halim. 2011. Hukum Lembaga Ekonomi Syariah di Indonesia. Banjarmasin: Nusa Media.

Barney, Jay. 1991. "Firm Resources and Sustained Competitive Advantage". Journal of Management. 17(1): 99-120.

David, Fred R. 2004. Strategic Management Manajemen Strategis Konsep. Jakarta: Penerbit Salemba Empat.

Departemen Ekonomi dan Keuangan Syariah, Bank Indonesia and Departemen Ekonomi Syariah Fakultas Ekonomi dan Bisnis, Universitas Airlangga. 2016.

Wakaf: Pengaturan dan Tata Kelola yang Efektif. Seri Ekonomi dan Keuangan Syariah.

Glueck, William F., and Lawrence R. Jauch. 1988. Business Policy and Strategy Management. Singapore: McGraw Hill.

Hunger, J. David and Thomas L. Wheelen. Essential of Strategic Management. New York: Pearson

Idri. 2015. Hadis Ekonomi. Jakarta: PT Kencana

Indrasari, Feny dan Tauran. 2016. "Implementasi Program Pembiayaan Usaha Syariah (PUSYAR) dalam Upaya Mensejahterakan Masyarakat Melalui Pembiayaan UMKM yang Dilaksanakan oleh Badan Amil Zakat Nasional (Baznas) Kota Mojokerto". Publika, 4 (10): 1-8.

Lembaga Administrasi Negara Republik Indonesia. 2008. Pemberdayaan Sumber Daya Manusia - Modul Diklatpim Tingkat III. Jakarta: Pemberdayaan Sumber Daya Manusia (PSDM), Lembaga Administrasi Negara

Maryati, Sri. (2014). "Peran Bank Pembiayaan Rakyat Syariah dalam Pengembangan UMKM dan Agribisnis Pedesaan di Sumatera Barat". Journal of Economic and Economic Education, 3 (1): 1-17.

Mubyarto. 2000. Membangun Sistem Ekonomi, BPFE, Yogyakarta: BPFE.

Nur Mahmudi Ismail. 2001. "Strategi Pemberdayaan Umat dan Pencetakan SDM Unggul" dalam Hotmatua Daulay dan Mulyanto, Membangun SDM dan Kapabilitas Teknologi Umat. Bandung: ISTECS.

Pusparani, Anisa, and Indah Prabawati Evaluasi. 2016. "Program Pembiayaan Usaha Syariah (PUSYAR) di Kota Mojokerto". Publika, 4 (11): 1-8.

Rahman. 2003. "Membangun Kepuasan dan Loyalitas Nasabah Melalui Atribut Produk, komitmen Agama, Kualitas Jasa dan Kepercayaan pada Bank Syariah (Studi Pada Bank Muamalat Cabang Semarang)," Jurnal Penelitian Walisongo, Pusat Penelitian IAIN Walisongo.

Rosyadi, Imron. 2013. "Strategi Pengembangan Usaha Mikro Milik Mahasiswa". Benefit Jurnal Manajemen dan Bisnis, 17 (2): 111-22.

Suharto, Edi. 2005. Membangun Masyarakat Memberdayakan Rakyat. Bandung: Reflika Aditama. 
Risanda A. Budiantoro, Pradipta P. Larasati, dan Sri Herianingrum

Umar, Husein. 2001. Strategic Management in Action. Jakarta: Gramedia Pustaka Utama

Wahyudi, Setyo Tri, M. Khusaini, and Devanto S. Pratomo. 2016. "Pemberdayaan Usaha Mikro Dan Kecil (UKM) Berbasis Syariah: Studi Pada Program PUSYAR Badan Amil Zakat Nasional (Baznas) Kota Mojokerto". Jurnal Pengabdian Kepada Masyarakat, 22 (3) 140-6. 